\title{
A Mutation in the tRNA Nucleotidyltransferase Gene Promotes Stabilization of mRNAs in Saccharomyces cerevisiae
}

\author{
STUART W. PELTZ, $\dagger$ JANET L. DONAHUE, AND ALLAN JACOBSON* \\ Department of Molecular Genetics and Microbiology, University of Massachusetts Medical School, \\ Worcester, Massachusetts 01655
}

Received 21 July 1992/Returned for modification 10 September 1992/Accepted 24 September 1992

\begin{abstract}
To identify trans-acting factors involved in mRNA decay in the yeast Saccharomyces cerevisiae, we have begun to characterize conditional lethal mutants that afiect mRNA steady-state levels. A screen of a collection of temperature-sensitive mutants identified ts352, a mutant that accumulated moderately stable and unstable mRNAs after a shift from 23 to $37^{\circ} \mathrm{C}$ (M. Aebi, G. Kirchner, J.-Y. Chen, U. Vijayraghavan, A. Jacobson, N. C. Martin, and J. Abelson, J. Biol. Chem. 265:16216-16220, 1990). ts352 has a defect in the CCA1 gene, which codes for tRNA nucleotidyltransferase, the enzyme that adds 3' CCA termini to tRNAs (Aebi et al., J. Biol. Chem., 1990). In a shift to the nonpermissive temperature, ts352 (ccal-1) cells rapidly cease protein synthesis, reduce the rates of degradation of the $C D C 4, T C M 1$, and $P A B 1 \mathrm{mRNAs}$ three- to fivefold, and increase the relative number of ribosomes associated with mRNAs and the overall size of polysomes. These results were analogous to those observed for cycloheximide-treated cells and are generally consistent with models that invoke a role for translational elongation in the process of mRNA turnover.
\end{abstract}

To a first approximation, changes in the expression of specific genes are manifested by changes in the steady-state levels of individual mRNAs. Although such changes are generally assumed to result primarily from differential transcription or RNA processing activities, differences in the decay rates of individual $\mathrm{mRNAs}$ can also have profound effects on the overall levels of expression of specific genes. While the potential importance of mRNA stability as a mechanism for regulating gene expression has been recognized (reviewed in references $2,6,13,27,31$, and 33), the structures and mechanisms involved in the determination of individual mRNA decay rates have yet to be elucidated.

We have begun an investigation of mRNA decay in the yeast Saccharomyces cerevisiae, an organism amenable to both biochemical and genetic manipulation (11). The principal hypothesis which guided our initial studies was that a comparison of the structures and properties of mRNAs that decayed rapidly versus those that decayed slowly would provide information about the basic rules of mRNA turnover $(15,26)$. Hence, our first objective was the identification of both stable and unstable mRNAs that were encoded by yeast genes that had already been well characterized. To accomplish this, we developed simple and reliable assays in which mRNA decay was analyzed after thermal or chemical inactivation of RNA polymerase II $(16,25)$. In addition to characterizing mRNA structural features that affect their decay rates, we have also been involved in determining the protein factors involved in mRNA turnover $(20,31)$. To identify trans-acting factors involved in the decay of inherently unstable mRNAs, we have begun to characterize conditional lethal mutants that affect the accumulation of such RNAs. A screen of a collection of temperature-sensi-

\footnotetext{
* Corresponding author.

$\dagger$ Present address: Department of Molecular Genetics and Microbiology, Robert Wood Johnson Medical School, University of Medicine and Dentistry of New Jersey, Piscataway, NJ 08854-5635.
}

tive mutants identified ts 352 , a mutant that accumulated moderately stable and unstable mRNAs after a shift from 23 to $37^{\circ} \mathrm{C}(1)$. Complementation of ts 352 with a yeast genomic DNA library led to the identification of the gene responsible for the temperature-sensitive lesion (1). ts 352 has a defect in the $C C A 1$ gene, which codes for tRNA nucleotidyltransferase, the enzyme that adds 3 ' CCA termini to tRNAs $(1,4)$. At the nonpermissive temperature, ts352 (cca1-1) cells accumulate tRNAs which are shorter than mature tRNAs because CCA termini are absent (1). In the experiments described in this report, we sought an explanation for the increases in mRNA steady-state levels observed in temperature-shifted ccal-1 cells. We report that reduction in the pool of functional tRNAs leads to a rapid decrease in the ability of cca1-1 cells to synthesize protein, a stabilization of transcripts, and a shift of mRNAs from lighter to heavier polysomes. These results were analogous to those observed in cycloheximide-treated cells and are generally consistent with models that invoke a role for translational elongation in the process of mRNA turnover.

\section{MATERIALS AND METHODS}

Yeast strains and media. ts 352 was originally identified in a collection of temperature-sensitive mutants (1). To isolate the mutation of interest (recently named cca1-1 [4]), ts352

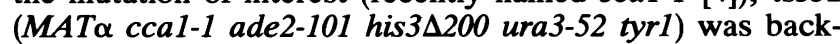
crossed by Aebi et al. (1) to the congenic strain SS328 (MATa ade2-101 his3 200 ura3-52 lys2). Temperature sensitivity of ts 352 was attributable to a single mutation because all 49 tetrads showed 2:2 segregation of the temperaturesensitive phenotype (1). Moreover, temperature sensitivity and increases in mRNA accumulation cosegregated in each of five tetrads examined (1). The segregants of one of these five tetrads, tetrad 1 (kindly provided by Nancy Martin), have the following genotypes: $M A T \alpha$ ccal-1 ade2-101 his3 200 ura3-52 hys2 (352-1A), MATa cca1-1 ade2-101

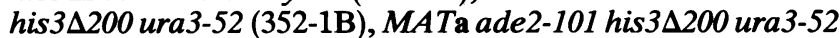




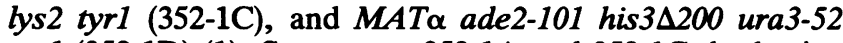
tyr1 (352-1D) (1). Segregants 352-1A and 352-1C, harboring the mutant (cca1-1) and wild-type (CCA1) tRNA nucleotidyltransferases, respectively, were used in the studies described in this report and are hereafter referred to as $1 \mathrm{~A}$ and 1C. Cells were grown in yeast extract-peptone-dextrose or synthetic complete medium lacking methionine (SC-Met) prepared as described elsewhere (35).

Measurement of translation rates. Cells were grown in SC-Met at $24^{\circ} \mathrm{C}$ to an optical density at $600 \mathrm{~nm}\left(\mathrm{OD}_{600}\right)$ of 0.5 to 0.7 . Cell cultures were shifted to $36^{\circ} \mathrm{C}$ by the addition of an equal volume of SC-Met preheated to $50^{\circ} \mathrm{C}$ and incubated thereafter at $36^{\circ} \mathrm{C}$. Aliquots of the culture $(1 \mathrm{ml})$ were removed to $1 \mu \mathrm{Ci}$ of $\left.{ }^{35} \mathrm{~S}\right]$ methionine $(15 \mathrm{mCi} / \mathrm{ml}, 38 \mathrm{TBq} /$ mmol; Amersham) and incubated for $4 \mathrm{~min}$ at $36^{\circ} \mathrm{C}$. Incorporation of labeled methionine was monitored by trichloroacetic acid (TCA) precipitation; $0.2 \mathrm{ml}$ of cold $\left(4^{\circ} \mathrm{C}\right) 50 \%$ TCA was added to each aliquot, after which the aliquots were incubated on ice for $10 \mathrm{~min}$, heated to $70^{\circ} \mathrm{C}$ for $20 \mathrm{~min}$, and subsequently filtered through $\mathrm{GF} / \mathrm{C}$ filters. The filters were washed with $10 \mathrm{ml}$ of $5 \%$ TCA $\left(4^{\circ} \mathrm{C}\right)$ and $10 \mathrm{ml}$ of $95 \%$ ethanol and then dried and counted in a scintillation counter.

Measurement of mRNA decay rates. As described previously $(16,25)$, decay rates of individual mRNAs were determined by RNA blotting analyses of RNA isolated at different times after inhibition of transcription with the antifungal agent thiolutin $(18,38)$ (generously provided by Nathan Belcher, Pfizer Central Research, Pfizer, Inc., Groton, Conn.). Cells were grown to an $\mathrm{OD}_{600}$ of approximately 0.70 (at temperatures indicated in the text), and thiolutin was added to $3 \mu \mathrm{g} / \mathrm{ml}$. For temperature shift experiments, cells were grown at $24^{\circ} \mathrm{C}$ to an $\mathrm{OD}_{600}$ of 0.70 , centrifuged, resuspended in $20 \mathrm{ml}$ of SC-Met, equilibrated to $24^{\circ} \mathrm{C}$, and then shifted to $36^{\circ} \mathrm{C}$ rapidly by the addition of $20 \mathrm{ml}$ of medium prewarmed to $50^{\circ} \mathrm{C}$. For RNA isolation, 4-ml aliquots were removed at the indicated times.

RNA extraction, RNA blotting, hybridization, and data analysis. RNA was isolated, and blots were prepared as described previously, using $20 \mu \mathrm{g}$ of RNA per lane (16). mRNA half-lives $\left(t_{1 / 2} s\right)$ were determined by hybridizing RNA blots with probes specific for the genes of interest. DNA probes used in these experiments included the following: PAB1 (SalI-EcoRI fragment from pYPA [16]), TCM1 (HindIII-EcoRI fragment from rfTCM1 [16]), HIS4 (SphISacI fragment from pUC18-HIS4 [16]), TRT1 (HindII-EcoRI fragment from pDH1 [16]), CDC4 (SalI fragment from p514100; kindly supplied by Stephen Johnson), and URA5 (KpnI-EcoRI fragment from pURA5; kindly supplied by Francois Lacroute). Decay rates, expressed as mRNA halflives, were determined by direct counting of RNA blots with a Betagen blot analyzer, normalization of the data such that time zero $\left(t_{0}\right)$ was equal to $100 \%$, and plotting of the data with respect to time on semilog axes $(16,25)$.

Polysome analysis. Cytoplasmic extracts, prepared as described by Baim et al. (3), were fractionated on 15 to $50 \%$ sucrose gradients buffered with $50 \mathrm{mM}$ Tris-acetate (pH 7.4)-50 mM $\mathrm{NH}_{4} \mathrm{Cl}-12 \mathrm{mM} \mathrm{MgCl}_{2}-1 \mathrm{mM}$ dithiothreitol. Gradients were centrifuged in an SW41 rotor at 40,000 rpm for $135 \mathrm{~min}$ at $4^{\circ} \mathrm{C}$ and analyzed by continuous monitoring of $A_{254}$ (24). No significant differences in recovery of ribosomes from mutant or wild-type cells were observed. To facilitate comparisons between different gradients, polysome-tomonosome ratios were determined by cutting and weighing the polysome and monosome regions of the respective gradient profiles. Unless stated otherwise, each experiment was repeated an average of five times.

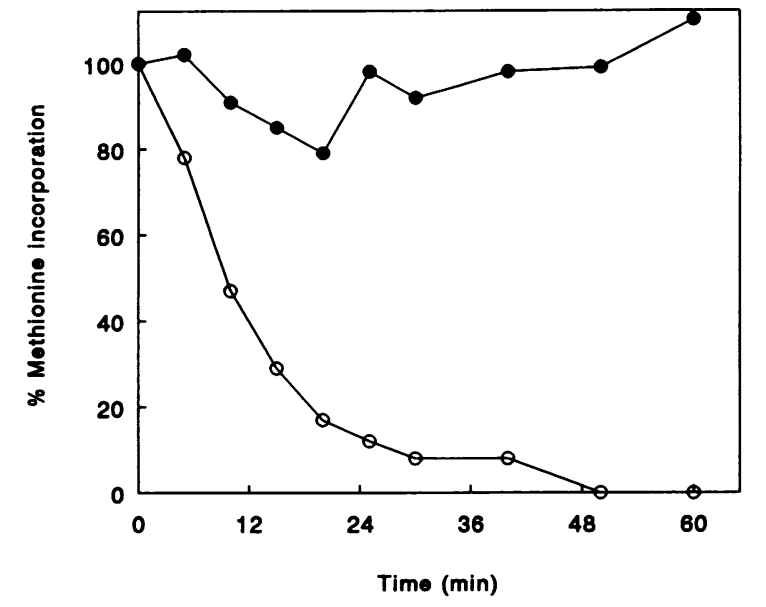

FIG. 1. Translation rates of wild-type and ccal-1 cells at $36^{\circ} \mathrm{C}$. Wild-type (segregant 352-1C; O) and ccal-1 (segregant 352-1A; O) cells were grown at $24^{\circ} \mathrm{C}$ and shifted abruptly to $36^{\circ} \mathrm{C}$; at various times after the temperature shift, translation rates were determined by pulse-labeling with $\left[{ }^{35} \mathrm{~S}\right]$ methionine. Data are presented as the percentage of methionine incorporation at a given time point compared with $t_{0}$ (for the same cells).

\section{RESULTS}

Protein synthesis is impaired at $36^{\circ} \mathrm{C}$ in ccal-1 cells. The effect of the ts352 mutation (also known as ccal-1 [4]) on protein synthesis was monitored by assaying the incorporation of radioactive methionine into protein during brief labeling periods. Cells harboring either the wild-type (CCA1) or mutant tRNA nucleotidyltransferase gene were shifted to $36^{\circ} \mathrm{C}$, and at various times after the temperature shift, incorporation of $\left[{ }^{35} \mathrm{~S}\right]$ methionine during a 4-min pulse was determined. When wild-type cells were shifted to $36^{\circ} \mathrm{C}$, their translation rate decreased transiently and then returned to initial rates by 40 to $60 \mathrm{~min}$ after the shift (Fig. 1). The translation rate of temperature-shifted ccal-1 cells displayed a different profile. When these cells were shifted to $36^{\circ} \mathrm{C}$, there was a rapid and continuous decrease in the translation rate (Fig. 1); by $50 \mathrm{~min}$ after the shift, less than $10 \%$ of the original translation activity remained. Consistent with the observed reduction in protein synthesis rates was a severe reduction in the growth rate of ccal-1 cells at temperatures above $32^{\circ} \mathrm{C}$ (Fig. 2).

mRNA decay rates in ccal-1 cells are reduced at the nonpermissive temperature. The results shown in Fig. 1 demonstrate that $c$ cal-1 cells cease protein synthesis rapidly at $36^{\circ} \mathrm{C}$. Since a considerable body of evidence suggests that mRNA translation and mRNA turnover are intimately linked (see reference 31 for a review), we sought to determine whether the elevated mRNA levels observed at the nonpermissive temperature in cells harboring the ccal-1 allele (1) might be attributable to reductions in mRNA decay rates. Using the drug thiolutin to inhibit transcription (16), we determined half-lives of several mRNAs at both the permissive $\left(24^{\circ} \mathrm{C}\right)$ and nonpermissive $\left(36^{\circ} \mathrm{C}\right)$ temperatures. At various times after thiolutin addition, cell aliquots were harvested, RNAs were isolated, and the decay of different transcripts was monitored by Northern (RNA) blotting, using probes for mRNAs that had been shown previously to have half-lives ranging from 3 to $18 \mathrm{~min}$ at $36^{\circ} \mathrm{C}(16,31)$. The results of these experiments demonstrate that at $24^{\circ} \mathrm{C}$, (i) decay rates of the CDC4,PAB1,TCM1, HIS4, URA5, and 

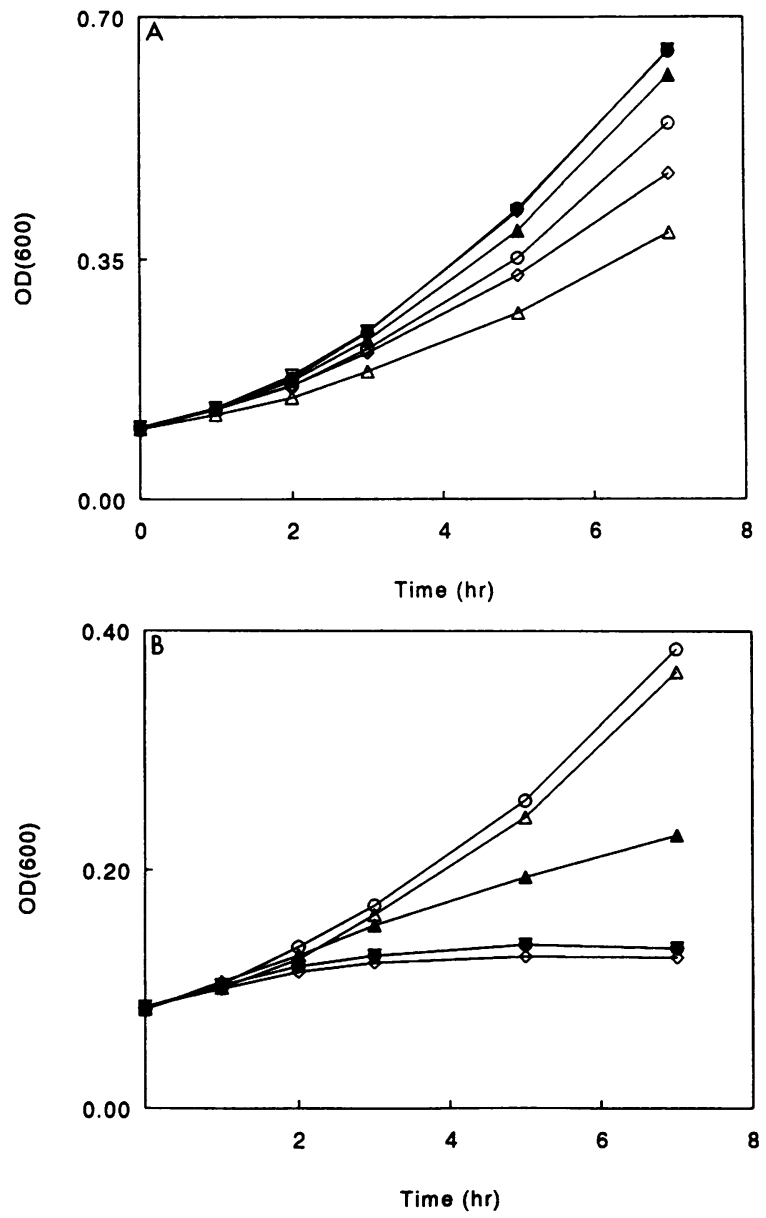

FIG. 2. Growth rates of wild-type and ccal-1 cells at different temperatures. Cultures of wild-type (segregant 352-1C; A) and ccal-1 (segregant 352-1A; B) cells were grown overnight at $24^{\circ} \mathrm{C}$ in medium lacking methionine. Aliquots of these cultures were diluted in the same medium and placed in separate flasks, and growth of the different cultures was monitored by measuring the $\mathrm{OD}_{600}$ for $\mathbf{7 ~ h}$ at $24^{\circ} \mathrm{C}(\triangle), 27^{\circ} \mathrm{C}(O), 30^{\circ} \mathrm{C}(\Delta), 32^{\circ} \mathrm{C}(\bullet), 34^{\circ} \mathrm{C}(\nabla)$, and $36^{\circ} \mathrm{C}(\diamond)$.

TRT1 mRNAs in cca1-1 cells were comparable to those observed in wild-type cells (Table 1) and (ii) in both mutant and wild-type cells, all mRNAs examined had slower decay rates at $24^{\circ} \mathrm{C}$ than had previously been measured at $36^{\circ} \mathrm{C}(16$,

TABLE 1. mRNA decay rates in mutant and wild-type cells at $24^{\circ} \mathrm{C}^{a}$

\begin{tabular}{lcc}
\hline \multirow{2}{*}{ mRNA } & \multicolumn{2}{c}{$t_{1 / 2}(\mathrm{~min})$} \\
\cline { 2 - 3 } & Wild type & cca1-1 allele \\
\hline PAB1 & 31 & 26 \\
CDC4 & 60 & 45 \\
TCM1 & 27.5 & 25.5 \\
HIS4 & 60 & 60 \\
URA5 & 25 & 25 \\
TRT1 & 40 & 40 \\
\hline
\end{tabular}

${ }^{a}$ Cultures of CCA1 (segregant 352-1C) or ccal-1 (segregant 352-1A) cells were grown at $24^{\circ} \mathrm{C}$ in SC-Met medium. Thiolutin was added to inhibit transcription, and relative levels of the CDC4, PAB1, TCM1, HIS4, URA5, and $T R T 1$ transcripts were measured by RNA blotting. mRNA half-lives were calculated as described previously (25).

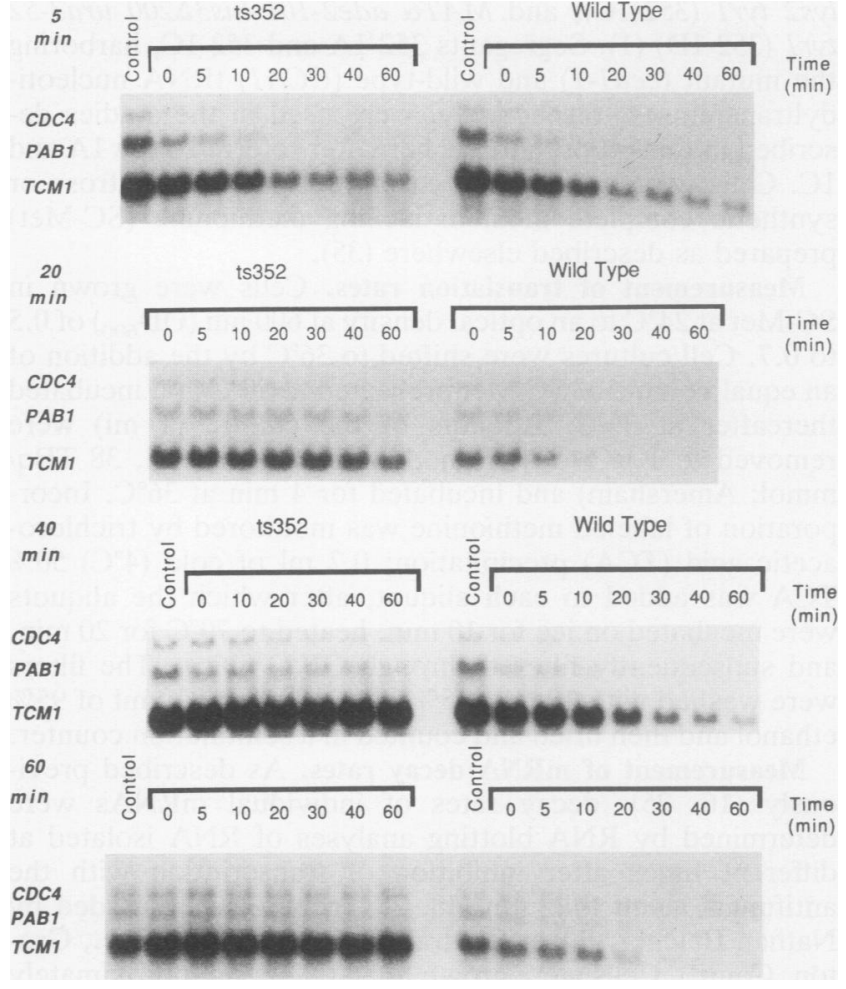

FIG. 3. mRNA decay in wild-type and cca1-1 cells after a shift to $36^{\circ} \mathrm{C}$. Cultures $(100 \mathrm{ml})$ of either segregant $352-1 \mathrm{~A}$ (wild type) or segregant 352-1C (ccal-1) were grown in SC-Met medium to an $\mathrm{OD}_{600}$ of 0.70 . The cells were centrifuged and resuspended in $20 \mathrm{ml}$ of the same medium, equilibrated for $10 \mathrm{~min}$ at $24^{\circ} \mathrm{C}$, and then shifted to $36^{\circ} \mathrm{C}$ by the addition of an equal volume of medium preheated to $50^{\circ} \mathrm{C}$. At $5,20,40$, and $60 \mathrm{~min}$ after the temperature shift, the decay rates of the $C D C 4, P A B 1$, and $T C M 1$ transcripts at $36^{\circ} \mathrm{C}$ were measured by removing aliquots of cells, inhibiting transcription with thiolutin, and monitoring transcript levels by RNA blot analysis. Control lanes contained RNA isolated from cells prior to the temperature shift.

31). Temperature-dependent changes in yeast mRNA decay rates have been reported previously (16).

To determine the effect of the ccal-1 mutation on mRNA degradation at the nonpermissive temperature, cell cultures were shifted to $36^{\circ} \mathrm{C}$, and at $5,20,40$, and $60 \mathrm{~min}$ after the temperature shift, decay of the PAB1, CDC4, and TCM1 mRNAs was analyzed by thiolutin inhibition of transcription and subsequent RNA blotting assays. The results from these experiments demonstrate that at $36^{\circ} \mathrm{C}$, mRNA degradation was three- to fivefold slower in ccal-1 cells than in cells containing the wild-type tRNA nucleotidyltransferase gene (Fig. 3; Table 2). The onset of mRNA stabilization in cca1-1 cells was rapid, occurring within 20 min of the temperature shift, a time when the translation rate was inhibited by approximately $80 \%$ (Fig. 1 and 4; Table 2). At both 40 and 60 min after the temperature shift, when translation rates in cca1-1 cells were reduced to $10 \%$ of their $t_{0}$ value, all transcripts examined were stable. In contrast, in cells harboring the wild-type tRNA nucleotidyltransferase gene, decay of the same transcripts was not stabilized at $36^{\circ} \mathrm{C}$. Rather, degradation of each of the transcripts examined in $\mathrm{CCAl}^{+}$cells was accelerated at the elevated temperature (Tables 1 and 2). 
TABLE 2. mRNA decay rates in mutant and wild-type cells shifted to $36^{\circ} \mathrm{C}$ for different lengths of time $e^{a}$

\begin{tabular}{|c|c|c|c|c|c|c|c|c|}
\hline \multirow{3}{*}{ mRNA } & \multicolumn{8}{|c|}{$t_{1 / 2}(\min )$} \\
\hline & \multicolumn{2}{|c|}{$5 \min ^{b}$} & \multicolumn{2}{|c|}{$20 \mathrm{~min}$} & \multicolumn{2}{|c|}{$40 \mathrm{~min}$} & \multicolumn{2}{|c|}{$60 \mathrm{~min}$} \\
\hline & WT & ts & WT & ts & WT & ts & WT & ts \\
\hline $\begin{array}{l}P A B 1 \\
T C M 1 \\
C D C 4\end{array}$ & $\begin{array}{r}7 \\
13 \\
12\end{array}$ & $\begin{array}{l}9.5 \\
10.5 \\
10\end{array}$ & $\begin{array}{r}13 \\
11 \\
9\end{array}$ & $\begin{array}{l}41 \\
31 \\
50\end{array}$ & $\begin{array}{l}17 \\
13 \\
10\end{array}$ & $\begin{array}{r}>60 \\
>60 \\
50\end{array}$ & $\begin{array}{l}13 \\
12 \\
14\end{array}$ & $\begin{array}{l}>60 \\
>60 \\
>60\end{array}$ \\
\hline
\end{tabular}

a Decay rates were calculated as described previously (25), using the data presented in Fig. 3. WT, wild-type cells; ts, ccal-1 cells.

b Time at $36^{\circ} \mathrm{C}$.

Comparison with mRNA decay rates in cells treated with cycloheximide. Cycloheximide-induced increases in mRNA abundance and decreases in mRNA decay rates have been observed previously for a large number of mRNAs in different experimental systems $(8,16,19,37,39$; reviewed in reference 27). Since inhibiting translation by mutation in a gene whose product is essential in protein synthesis also stabilizes mRNAs (Fig. 1 and 4), it is likely that cycloheximide effects on mRNA decay are not drug-related artifacts but rather may be indicative of a requirement for translational elongation in the decay of mRNA. To compare directly the effects of cycloheximide with the results obtained with cca1-1, the half-lives of six transcripts from $\mathrm{CCAl}^{+}$ cells were determined in the presence or absence of cycloheximide. A culture of wild-type cells was divided in half; one culture was treated with cycloheximide for $\mathbf{4 0} \mathrm{min}$, while the second culture was left untreated. Subsequently, transcription was inhibited by the addition of thiolutin, and mRNA decay rates were determined. The results demonstrate that the half-lives of all six transcripts were increased in the presence of cycloheximide (Fig. 4; Table 3) and that the extent of mRNA stabilization was comparable to that observed in ccal-1 cells shifted to the nonpermissive temperature for at least 40 to $60 \mathrm{~min}$ (Fig. 3; Table 2).

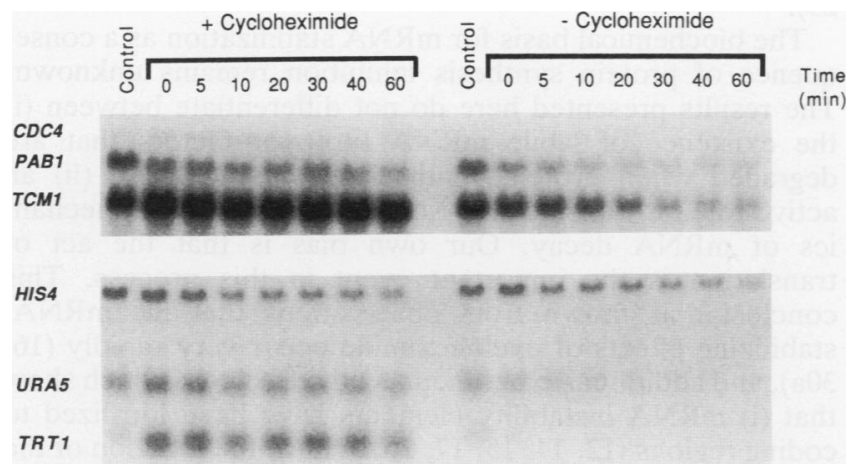

FIG. 4. mRNA decay at $36^{\circ} \mathrm{C}$ in the presence and absence of cycloheximide. Wild-type cells $(200 \mathrm{ml}$; segregant $352-1 \mathrm{C})$ were grown at $24^{\circ} \mathrm{C}$ to an $\mathrm{OD}_{600}$ of 0.7 , centrifuged, resuspended in $36 \mathrm{ml}$ of SC-Met medium, and divided into two equal aliquots. Cultures were shifted to $36^{\circ} \mathrm{C}$ by the addition of $18 \mathrm{ml}$ of the same medium preheated to $50^{\circ} \mathrm{C}$ and either containing or lacking cycloheximide. The final cycloheximide concentration was $125 \mu \mathrm{g} / \mathrm{ml}$. Forty minutes after addition of medium, the relative levels of the $C D C 4$, $P A B 1, T C M 1, H I S 4, U R A 5$, and TRT1 transcripts were measured by inhibiting transcription with thiolutin and monitoring transcript levels by RNA blot analysis. Control lanes contained RNA isolated from cells prior to the temperature shift.
TABLE 3. mRNA decay rates in the presence and absence of cycloheximide ${ }^{a}$

\begin{tabular}{lcc}
\hline \multirow{2}{*}{ mRNA } & \multicolumn{2}{c}{$t_{1 / 2}(\mathrm{~min})$} \\
\cline { 2 - 3 } & -Cycloheximide & +Cycloheximide \\
\hline PAB1 & 14 & 40 \\
CDC4 & 18 & $>60$ \\
TCM1 & 18.5 & $>60$ \\
HIS4 & 40 & $>60$ \\
URA5 & 18 & $>60$ \\
TRT1 & 22 & $>60$ \\
\hline
\end{tabular}

a Decay rates were calculated as described previously (25), using the data presented in Fig. 4.

Inhibiting translation by either cycloheximide treatment or the ccal-1 mutation causes polysomes to accumulate. The results shown in Fig. 3 and 4 indicate that inhibition of protein synthesis, either by cycloheximide addition or by a mutation in the tRNA nucleotidyltransferase gene, leads to
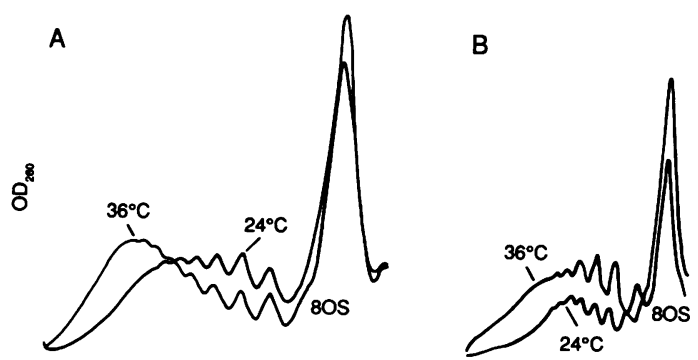

SEDIMENTATION

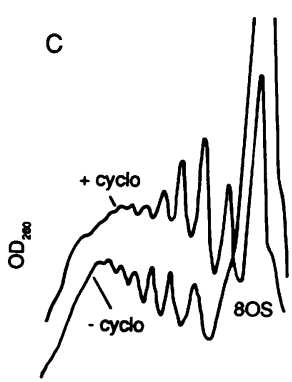

FIG. 5. Polysome profiles of wild-type and mutant cells. Wildtype (segregant 352-1C) or mutant (segregant 352-1A) cells were grown at different temperatures in the presence or absence of cycloheximide. Cells were harvested, and cytoplasmic extracts were prepared and fractionated on sucrose gradients as described in Materials and Methods. (A) Wild-type cells were grown at $24^{\circ} \mathrm{C}$ in SC-Met medium $(500 \mathrm{ml})$ to an $\mathrm{OD}_{600}$ of 0.7 , centrifuged, and resuspended in $300 \mathrm{ml}$ of the same medium. Aliquots $(100 \mathrm{ml})$ were placed into separate flasks and equilibrated at $24^{\circ} \mathrm{C}$ for $10 \mathrm{~min}$. An equal volume of preheated medium was added to each culture so that the final temperatures in these cultures were 24,30 , and $36^{\circ} \mathrm{C}$, respectively. Incubation at these temperatures was continued for an additional $\mathbf{4 0} \mathrm{min}$ prior to collection of cells for polysome analysis. Shown here are the results from the 24 and $36^{\circ} \mathrm{C}$ cultures; results from all three cultures are summarized in Table 4. (B) Mutant cells were analyzed as described above for wild-type cells. (C) Wild-type cells were grown at $24^{\circ} \mathrm{C}$ in SC-Met medium $\left(340 \mathrm{ml}\right.$ ) to an $\mathrm{OD}_{600}$ of 0.7 , centrifuged, resuspended in $200 \mathrm{ml}$ of the same medium, and then divided into two 100-ml aliquots. Cycloheximide (cyclo) was added to one aliquot at a final concentration of $125 \mu \mathrm{g} / \mathrm{ml}$, while the other culture was untreated. The cells were incubated for $40 \mathrm{~min}$, and polysomes were then prepared and analyzed. 
TABLE 4. Polysome/monosome ratios in mutant and wildtype cells ${ }^{a}$

\begin{tabular}{cccc}
\hline & \multicolumn{3}{c}{ Polysome/monosome ratio } \\
\cline { 2 - 4 } Temp $\left({ }^{\circ} \mathrm{C}\right)$ & Wild type & ts352 & $\begin{array}{c}\text { Wild type }+ \\
\text { cycloheximide }\end{array}$ \\
\hline 24 & $1.26 \pm 0.27$ & $0.80 \pm 0.22$ & ND \\
30 & $1.19 \pm 0.23$ & $0.88 \pm 0.18$ & $6.01 \pm 0.40$ \\
36 & $1.19 \pm 0.25$ & $2.39 \pm 0.31$ & ND \\
\hline
\end{tabular}

${ }^{a}$ Polysomes were prepared and analyzed on 15 to $50 \%$ sucrose gradients as described in the legend to Fig. 5. The ratios of polysomes to monosomes were calculated as described in Materials and Methods. Each analysis was repeated five times, with the exception of the cycloheximide experiments, which were repeated twice. Data are averages of all experiments. ND, not determined.

stabilization of mRNAs. Previous studies have shown that cycloheximide-mediated reductions in translational elongation rates lead to increases in the relative amounts of heavy polysomes $(7,21)$. To compare further the mechanisms of mRNA stabilization in cycloheximide-treated cells versus temperature-shifted ccal-1 cells, polysome profiles of cells grown under (or shifted to) three different conditions were analyzed. (i) Wild-type cells were grown at 24,30 , and $36^{\circ} \mathrm{C}$, (ii) ccal-1 cells were grown at 24,30 , and $36^{\circ} \mathrm{C}$, and (iii) wild-type cells were grown in the presence or absence of cycloheximide at $30^{\circ} \mathrm{C}$. Polysomes from these cultures were prepared and analyzed on sucrose gradients; the results are summarized in Fig. 5 and Table 4. The results of these experiments indicate that when wild-type cells are grown at different temperatures, there is a slight increase in the amount of heavy polysomes at $36^{\circ} \mathrm{C}$, but the ratio of polysomes to monosomes does not vary significantly as a function of temperature (Table 4). In ccal-1 cells, however, the polysome-to-monosome ratio in cells shifted to $36^{\circ} \mathrm{C}$ increased threefold relative to that observed in the same cells grown at 24 or $30^{\circ} \mathrm{C}$ (Table 4). For comparison, the polysome profiles of wild-type cells grown at $30^{\circ} \mathrm{C}$ in the presence or absence of cycloheximide were also analyzed. The results of these experiments demonstrate that cycloheximide increases the polysome-to-monosome ratio approximately sixfold (Fig. 5; Table 4). Collectively, the results summarized in Table 4 indicate that when protein synthesis was inhibited, either by shifting cca1-1 cells to the nonpermissive temperature or by the addition of cycloheximide to the cell cultures, the overall number of ribosomes per transcript increased.

\section{DISCUSSION}

We report here that following a shift to $36^{\circ} \mathrm{C}$, cells harboring a temperature-sensitive mutation (ccal-1) in the yeast tRNA nucleotidyltransferase gene rapidly cease protein synthesis, reduce their rates of mRNA degradation, and increase the relative number of ribosomes associated with mRNAs. These observations lead us to draw the following conclusions about tRNA and mRNA metabolism in $S$. cerevisiae.

The rapid decrease of protein synthesis at $36^{\circ} \mathrm{C}$ in strains harboring the ccal-1 allele indicates that there is most likely a rapid equilibrium between tRNAs containing or lacking $3^{\prime}$ CCA termini. This conclusion is supported by experiments reported previously (1) in which it was shown that (i) temperature shifts of $c$ cal-1 cells lead to the accumulation of tRNAs that are shorter than normal, (ii) such shorter tRNAs are better substrates for terminal CCA addition in vitro than are wild-type tRNAs (i.e., the shorter tRNAs must be generally lacking CCA termini), and (iii) such tRNA shortening begins immediately after the shift to the nonpermissive temperature. A comparison of the polysome profiles of temperature-shifted cca1-1 and wild-type cells suggests that the reduction in the pool of functional tRNAs has its primary effect on translational elongation. After a shift to $36^{\circ} \mathrm{C}$, cca1-1 cells increase the overall number of ribosomes per mRNA, as evidenced by a threefold increase in the ratio of polysomes to monosomes and an overall shift to larger polysomes. This effect is comparable to that observed in cycloheximide-treated cells (Fig. 5; Table 4) and generally considered to be diagnostic of a reduction in translational elongation rates $(7,21)$. It should be noted, however, that the magnitude of the effect on polysome profiles in cycloheximide-treated cells was greater; cells treated with cycloheximide prior to the preparation of polysomes increased their polysome/monosome ratio sixfold (Table 4). Although the reason for this difference is not clear at present, we consider it possible that the cca1-1 mutation also interferes with translational initiation. If the CCA termini of all (or most) tRNAs are comparably affected in temperature-shifted cca1-1 cells, then the initiator methionine tRNA should not be efficiently charged and translational initiation rates may be reduced. Cycloheximide, on the other hand, appears to affect only translational elongation $(7,21,32)$.

The reduction in mRNA decay rates that paralleled the reduction in protein synthesis activity suggests that ongoing translation is essential for the decay of most mRNAs. The latter conclusion is supported by the reduced mRNA decay rates observed in cycloheximide-treated cells (Fig. 4; Table 3) $(8,19,37,39$; reviewed in reference 27$)$ and provides an explanation for the increased steady-state levels of the $S T E 3, P A B 1$, and TCM1 transcripts observed in the initial screen that resulted in the identification of the ccal-1 mutant (1). Moreover, since inhibiting translation by mutation is an event distinctly different from treating cells with a drug, these results substantiate the significance of previous studies in which cycloheximide stabilized mRNAs $(16,19,37,39)$ and minimize the possibility that the stabilization of cellular transcripts by cycloheximide is due to secondary effects, e.g., cycloheximide effects on protein phosphorylation (22, 23).

The biochemical basis for mRNA stabilization as a consequence of protein synthesis inhibition remains unknown. The results presented here do not differentiate between (i) the existence of labile mRNA turnover factors that are degraded when protein synthesis is inhibited and (ii) an active role for translocating ribosomes in the actual mechanics of mRNA decay. Our own bias is that the act of translation is the important event in this process. This conclusion is drawn from observations that the mRNAstabilizing effects of cycloheximide occur very rapidly (16, $30 \mathrm{a}$ ), and additional experiments with yeast cells which show that (i) mRNA instability elements have been localized to coding regions $(12,14,15,17,26,31)$, (ii) the function of the coding region instability element from the $M A T \alpha 1$ mRNA is dependent on ribosome progression up to or through the element (26), and (iii) destabilization of mRNAs by premature translational termination requires downstream sequences that appear to act as translational reinitiation sites $(30,31)$. In addition to these observations for yeast cells, experiments with mammalian cells demonstrate that (i) the nucleases capable of degrading mammalian mRNAs in vitro are associated with polysomes $(29,34)$, (ii) the exonuclease activity that degrades histone mRNA in a cell-free mRNA decay system is not affected by treating the cells with 
cycloheximide (28), (iii) sequences in the coding regions of the $\beta$-tubulin, $c-m y c$, and $c-f o s$ genes are important for rapid or regulated turnover of their transcripts $(5,36,39)$, and (iv) the regulation of tubulin, histone, and c-myc mRNA turnover requires ongoing protein synthesis $(9,10,36)$. Collectively, these results suggest an important role for the ribosome (or one of its subunits) in the decay process. This role may simply be passive, i.e., translation of a sufficient number of codons to expose a nascent peptide critical to the turnover of the respective mRNA (5), or active, e.g., as a component of the site recognition machinery (27) or as the agent which delivers or activates a specific nuclease $(10,26$, 31).

The mRNA-stabilizing effects of the ccal-1 mutation, and all of the other experimental evidence linking mRNA translation and turnover, suggest that genetic schemes to identify mutations in mRNA decay pathways must be approached cautiously. Mutations that alter protein synthesis may, indirectly, alter mRNA decay rates; i.e., it may often be difficult to determine whether a mutation that alters turnover rates is directly or indirectly involved in the decay process.

\section{ACKNOWLEDGMENTS}

This work was supported by grant GM27757 to A.J. from the National Institutes of Health and by a postdoctoral fellowship to S.W.P. from the American Cancer Society.

We thank Christine Bonczek and Agneta Brown for technical help, Nancy Martin for the segregants of the ts 352 backcross, and He Feng and Ellen Welch for critical reading of the manuscript.

\section{REFERENCES}

1. Aebi, M., G. Kirchner, J.-Y. Chen, U. Vijayraghavan, A. Jacobson, N. C. Martin, and J. Abelson. 1990. Isolation of a temperature-sensitive mutant with an altered tRNA nucleotidyltransferase and cloning of the gene encoding tRNA nucleotidyltransferase in the yeast Saccharomyces cerevisiae. J. Biol. Chem. 265:16216-16220.

2. Atwater, J. A., R. Wisdom, and I. M. Verma. 1990. Regulated mRNA stability. Annu. Rev. Genet. 24:519-541.

3. Baim, S. B., D. F. Pietras, D. C. Eustice, and F. Sherman. 1985. A mutation allowing an mRNA secondary structure diminishes translation of Saccharomyces cerevisiae iso-1-cytochrome $c$. Mol. Cell. Biol. 5:1839-1846.

4. Chen, J. Y., P. B. M. Joyce, C. L. Wolfe, M. C. Steffen, and N. C. Martin. Cytoplasmic and mitochondrial tRNA nucleotidyltransferase activities are derived from the same gene in the yeast Saccharomyces cerevisiae. J. Biol. Chem. 267:1487914883.

5. Cleveland, D. W. 1988. Autoregulated instability of tubulin mRNAs: a novel eukaryotic regulatory mechanism. Trends Biochem. Sci. 13:339-343.

6. Cleveland, D. W., and T. J. Yen. 1989. Multiple determinants of eukaryotic mRNA stability. New Biol. 1:121-126.

7. Fan, H., and S. Penman. 1970. Regulation of protein synthesis in mammalian cells. II. Inhibition of protein synthesis at the level of initiation during mitosis. J. Mol. Biol. 50:655-670.

8. Fort, P., J. Rech, A. Vie, M. Piechaczyk, A. Bonnieu, P. Jeanteur, and J. M. Blanchard. 1987. Regulation of $c$-fos gene expression in hamster fibroblasts: initiation and elongation of transcription and mRNA degradation. Nucleic Acids Res. 15: 5657-5667.

9. Gay, D. A., S. S. Sisodia, and D. W. Cleveland. 1989. Autoregulatory control of $\beta$-tubulin mRNA stability is linked to translation elongation. Proc. Natl. Acad. Sci. USA 86:5763-5767.

10. Graves, R. A., N. B. Pandey, N. Chodchoy, and W. F. Marzluff. 1987. Translation is required for regulation of histone mRNA degradation. Cell 48:615-626.

11. Guthrie, C., and G. R. Fink (ed.). 1991. Methods in enzymology: molecular biology of Saccharomyces cerevisiae. Academic Press, New York.
12. Heaton, B., C. Decker, D. Muhlrad, J. Donahue, A. Jacobson, and R. Parker. Analysis of chimeric mRNAs identifies two regions within the STE3 mRNA which promote rapid mRNA decay. Nucleic Acids Res., in press.

13. Hentze, M. W. 1991 . Determinants and regulation of cytoplasmic mRNA stability in eukaryotic cells. Biochim. Biophys. Acta 1090:281-292.

14. Herrick, D. 1989. Structural determinants of mRNA turnover in yeast. Ph.D. thesis. University of Massachusetts Medical School, Worcester.

15. Herrick, D., and A. Jacobson. 1992. A segment of the coding region is necessary but not sufficient for rapid decay of the HIS 3 mRNA in yeast. Gene 114:35-41.

16. Herrick, D., R. Parker, and A. Jacobson. 1990. Identification and comparison of stable and unstable mRNAs in Saccharomyces cerevisiae. Mol. Cell. Biol. 10:2269-2284.

17. Jacobson, A., A. H. Brown, J. L. Donahue, D. Herrick, R. Parker, and S. W. Peltz. 1990. Regulation of mRNA stability in yeast, p. 45-54. In J. E. G. McCarthy and M. F. Truite (ed.), Post-transcriptional regulation of gene expression. SpringerVerlag, Berlin.

18. Jimenez, A., D. J. Tipper, and J. Davies. 1973. Mode of action of thiolutin, an inhibitor of macromolecular synthesis in Saccharomyces cerevisiae. Antimicrob. Agents Chemother. 3:729-738.

19. Kelly, K., B. H. Cochran, C. D. Stiles, and P. Leder. 1983. Cell specific regulation of the $c-m y c$ gene by lymphocyte mitogens and platelet-derived growth factor. Cell 35:603-610.

20. Leeds, P., S. W. Peltz, A. Jacobson, and M. R. Culbertson. 1991. The product of the yeast $U P F 1$ gene is required for rapid turnover of mRNAs containing a premature translational termination codon. Genes Dev. 5:2303-2314.

21. Lodish, H. F. 1971. Alpha and beta globin messenger ribonucleic acid-different amounts and rate of translation. J. Biol. Chem. 246:7131-7138.

22. Mahadevan, L. C., and D. R. Edwards. 1991. Signalling and superinduction. Nature (London) 349:747-748.

23. Mahadevan, L. C., A. C. Willis, and M. J. Barratt. 1991. Rapid histone H3 phosphorylation in response to growth factors, phorbol esters, okadaic acid, and protein synthesis inhibitors. Cell 65:775-783

24. Manrow, R. E., and A. Jacobson. 1986. Identification and characterization of developmentally regulated mRNP proteins of Dictyostelium discoideum. Dev. Biol. 116:213-227.

25. Parker, R., D. Herrick, S. W. Peltz, and A. Jacobson. 1991. Measurement of mRNA decay rates in Saccharomyces cerevisiae. Methods Enzymol. 194:415-423.

26. Parker, R., and A. Jacobson. 1990. Translation and a forty-two nucleotide segment within the coding region of the mRNA encoded by the $M A T \alpha l$ gene are involved in promoting rapid mRNA decay in yeast. Proc. Natl. Acad. Sci. USA 87:2780 2784.

27. Peltz, S. W., G. Brewer, P. Bernstein, R. Kratzke, and J. Ross. 1991. Regulation of mRNA turnover in eucaryotic cells. Crit. Rev. Eukaryotic Gene Expression 1:99-126.

28. Peltz, S. W., G. Brewer, V. Groppi, and J. Ross. 1989. The exonuclease activity that degrades histone mRNA remains a stable activity throughout the cell cycle. Mol. Biol. Med. 6:227-238

29. Peltz, S. W., G. Brewer, G. Kobs, and J. Ross. 1987. Substrate specificity of the exonuclease activity that degrades $\mathrm{H} 4$ histone mRNA. J. Biol. Chem. 262:9382-9388.

30. Peltz, S. W., A. H. Brown, and A. Jacobson. Unpublished data. 30a.Peltz, S. W., J. L. Donahue, and A. Jacobson. Unpublished data.

31. Peltz, S. W., and A. Jacobson. mRNA turnover in Saccharomyces cerevisiae. In G. Brawerman and J. Belasco (ed.), Control of mRNA stability, in press. Academic Press, New York.

32. Rose, J. K., and H. F. Lodish. 1976. Translation in vitro of vesicular stomatitis virus mRNA lacking 5'-terminal 7-methylguanosine. Nature (London) 262:32-37.

33. Ross, J. 1988. Messenger RNA turnover in eukaryotic cells. Mol. Biol. Med. 5:1-14.

34. Ross, J., and G. Kobs. 1986. H4 histone messenger RNA decay in cell-free extracts initiates at or near the $3^{\prime}$ terminus and 
proceeds $3^{\prime}$ to 5'. J. Mol. Biol. 188:579-593.

35. Sherman, F., G. R. Fink, and J. B. Hicks. 1986. Laboratory course manual for methods in yeast genetics. Cold Spring Harbor Laboratory Press, Cold Spring Harbor, N.Y.

36. Shyu, A.-B., M. E. Greenberg, and J. G. Belasco. 1989. The $c$-fos transcript is targeted for rapid decay by two distinct mRNA degradation pathways. Genes Dev. 3:60-72.

37. Stimac, E., V. E. Groppi, Jr., and P. Coffino. 1984. Inhibition of protein synthesis stabilizes histone mRNA. Mol. Cell. Biol. 4:2082-2090.

38. Tipper, D. J. 1973. Inhibition of yeast ribonucleic acid polymerases by thiolutin. J. Bacteriol. 116:245-256.

39. Wisdom, $\mathbf{R}$., and $\mathbf{W}$. Lee. 1991. The protein-coding region of c-myc mRNA contains a sequence that specifies rapid mRNA turnover and induction by protein synthesis inhibitors. Genes Dev. 5:232-243. 